\title{
Pengaruh Infeksi Trypanosoma evansi terhadap Kadar TNF- $\alpha$ dan Perubahan Histopatologi Hepar pada Tikus Putih (Rattus norvegicus)
}

\author{
Ady Kurnianto $^{1 *}$, Junianto Wika Adi Pratama ${ }^{1}$, Miranti Candrarisna ${ }^{2}$ \\ Departemen IImu Penyakit Dalam Veteriner Fakultas Kedokteran Hewan ${ }^{1}$ \\ Departemen Farmakologi dan Farmasi Fakultas Kedokteran Hewan ${ }^{2}$ \\ Universitas Wijaya Kusuma Surabaya \\ *e-mail: adykurniantodvm@gmail.com
}

\begin{abstract}
Abstrak
Tujuan penelitian ini adalah untuk menganalisis kadar Tumor necrosis Factor a(TNF- $\alpha$ ) dan derajat kerusakan hepar pada tikus putih (Rattus norvegicus) yang diinfeksi isolat Trypanosoma evansi. Penelitian ini adalah penelitian eksperimental dengan Rancangan Acak Lengkap (RAL). Sampel Hewan adalah tikus jantan umur 6 minggu sebanyak 30 ekor dan dibagi dalam 5 kelompok dengan pemberian infeksi secara subcutan (sc), yaitu Po: kelompok tikus kontrol diinjeksi $\mathrm{NaCl}$ fisiologis dosis $0,3 \mathrm{ml}$, pengambilan sampel darah dan organ hepar pada hari ke 7 pasca injeksi $\mathrm{NaCl}$ fisiologis. P1: kelompok tikus diinfeksi Trypanosoma evansi dosis $0,3 \mathrm{ml} / \mathrm{sc}$, pengambilan sampel darah dan organ hepar pada hari pertama pasca infeksi Trypanosoma evansi. P2: kelompok tikus diinfeksi Trypanosoma evansi dosis $0,3 \mathrm{ml} / \mathrm{sc}$, pengambilan sampel darah dan organ hepar pada hari ke 3 pasca infeksi Trypanosoma evansi. P3: kelompok tikus diinfeksi Trypanosoma evansi dosis: 0,3 ml/sc, pengambilan sampel darah dan organ hepar pada hari ke 5 pasca infeksi Trypanosoma evansi. P4: kelompok tikus putih diinfeksi Trypanosoma evansi dosis $0,3 \mathrm{ml} / \mathrm{sc}$, pengambilan sampel darah dan organ hepar pada hari ke 7 pasca infeksi Trypanosoma evansi. Nilai Optical Density (OD) atau kadarTNF-amenunjukkan $p=0,0624(p>0,05)$, mengalami penurunan dan tidak berbeda, dan tidak terdapat hubungan bermakna antara kelompok pada tikus putih yang diinfeksi Trypanosoma evansi isolat Sumbawa. Pemberian infeksi secara subkutan dapat menyebabkan kerusakan hepar berupa lesi degenerasi, nekrosis, dan portal inflamasi pada tikus putih yang diinfeksi Trypanosoma evansi isolat Sumbawa. Kesimpulan adalah kadar TNF- $\alpha$ menurun, mengakibatkan kerusakan hepar dan tingkat keganasan parasit Trypanosoma evansi isolat Sumbawa meningkat.
\end{abstract}

Kata Kunci: Hepar, kadar TNF- $\alpha$, Trypanosoma evansi

\section{Effect of Trypanosoma evansi Infection on TNF- $\alpha$ Levels and Liver Histopathological Changes in White Rats (Rattus norvegicus)}

\begin{abstract}
The purpose of this study was to analyze the levels of Tumor necrosis Factor a (TNF- $\alpha$ ) and the degree of liver damage in white rats infected with isolates Trypanosoma evansi. This study was an experimental study using a completely randomized design (CRD). Animal samples used were male rats aged 6 weeks as many as 30 mice infected by Trypanosoma evansi subcutan (sc), and divided into 5 groups: Po: groups of control rats injected with physiological $\mathrm{NaCl}$ dose of $0.3 \mathrm{ml}$, taking blood samples and liver organs on the 7th day after injection of physiological NaCl. P1: rat group infected with a dose of $0.3 \mathrm{ml} / \mathrm{sc}$ of Trypanosoma evansi, blood sampling and liver
\end{abstract}


Pengaruh Infeksi Trypanosoma evansi terhadap Kadar TNF- $\alpha$ dan Perubahan Histopatologi... Ady Kurnianto, Junianto Wika Adi Pratama, Miranti Candrarisna

organ on the first day after Trypanosoma evansi infection. P2: a group of rats infected with a dose of $0.3 \mathrm{ml} / \mathrm{sc}$ of Trypanosoma evansi, blood sampling and liver organ on the third day after Trypanosoma evansi infection. P3: group of rats infected with Trypanosoma evansi dose: $0.3 \mathrm{ml} / \mathrm{sc}$, blood sampling and liver organ on the 5th day after Trypanosoma evansi infection. P4: groups of white rats infected with a dose of $0.3 \mathrm{ml} / \mathrm{sc}$ of Trypanosoma evansi, taking blood samples and liver organs on the 7th day after Trypanosoma evansi infection. Optical Density (OD) values or TNF- $\alpha$ levels showed $p=0,0624(p>0,05)$, decreased and did not differ, and there was no significant relationship between groups in Sumbawa isolates infected with Trypanosoma evansi white rats. Subcutaneous infection can cause liver damage in the form of degenerative lesions, necrosis and inflammatory portal in Sumbawa isolates infected with Trypanosoma evansiwhite rats. Conclusion: TNF- $\alpha$ levels decreased, resulting in liver damage and parasitic malignancy levels of Trypanosoma evansi Sumbawa isolates increased.

Keywords: Liver, TNF- $\alpha$ level, Trypanosoma evansi

\section{PENDAHULUAN}

Trypanosomiasis merupakan salah satu penyakit hewan menular berbahaya dari hewan ternak ke manusia. Trypanosomiasis terutama terjadi pada kuda, sapi dan kerbau disebabkan oleh Trypanosoma evansi. Penyebaran protozoa Trypanosoma evansi ini sangat luas, hampir di seluruh pulau besar di Indonesia. Trypanosoma evansi ini dapat menyerang berbagai jenis hewan ternak dan satwa liar. Kejadian penyakit sangat bervariasi tergantung pada faktor yang mempengaruhi hospes. Hewan unta, kuda dan anjing sangat peka terhadap infeksi Trypanosoma evansi. Penyakit ini terjadi secara cepat, bersifat akut bahkan dapat berakibat fatal. Penularan trypanosomiasis terutama terjadi didaerah tropis. Trypanosomiasis tergolong kepada penyakit re-emerging diseases di dunia, terutama di negara Asia, Afrika dan Amerika latin (WHO,2010; WHO, 2012). Infeksi Trypanosoma pertama kali terjadi pada tahun 1880 pada unta dan bangsa kuda di India. Penyakit ini menjadi wabah penyakit berbahaya pada kuda, unta dan kerbau di beberapa wilayah di India. Trypanosomiasis atau Surra, endemik di daerah Asia Tenggara dan juga ditemukan di Indonesia. Penyakit ini telah menimbulkan banyak kerugian secara ekonomi diantaranya pertumbuhan hewan yang lambat, penurunan produksi bahkan dapat menimbulkan kematian hewan tersebut. Kerugian akibat kematian hewan ternak yang ditimbulkan oleh Trypanosoma evansi diperkirakan mencapai ratusan miliar rupiah setiap tahun. Trypanosomiasis juga dapat menyebabkan masyarakat kehilangan pekerjaannya (peternak). 
Selain itu Tripanosomiasis juga menyebabkan penurunan bobot badan ternak, abortus akibat gangguan pada reproduksi (Dobson et al, 2009; Dargantes et al, 2009).

Trypanosomiasis merupakan penyakit yang bersifat endemis di beberapa daerah di Indonesia seperti Bali, Sumbawa, Jawa (Pemalang, Banten), Madura dan lain-lainnya. Wabah penyakit Surra sering terjadi di Indonesia, diantaranya dilaporkan terjadi di Provinsi Banten yang menyebabkan beberapa ternak mati pada tahun 2014. Sejak tahun 2013, penyakit Surra dimasukkan kembali ke daftar penyakit strategis karena setelah tahun 2007 penyakit dilaporkan menyebar dari daerah endemis ke daerah bukan endemis. Akibat wabah penyakit ini,ratusan ekor ternak besar dilaporkan mati dan ribuan lainnya menderita sakit dan terancam mati jika tidak mendapatkan pengobatan yang secara cepat(Ngure et al, 2009; Mekata et al, 2013).

Populasi ternak sapi, kerbau dan kuda, terutama produksi daging atau produksi susu hasil ternak pada daerah endemis penyakit surra akan mengalami penurunan produksi. Pada pulau Sumbawa pada tahun 2009, tercatat sebanyak 283.656 ekor, 317.084 ekor dan 60.964 ekor. Salah satu faktor penurunan produksi tersebut dikarenakan terjadinya penurunan pada sistem pertahanan tubuh dari ternak akibat Trypanosomiasis. Jika dibiarkan lama dapat menyebabkan gangguan pada aktivitas dan kesehatan ternak. Manusia dapat tertular Trypanosomiasis di Sumbawa apabila terinfeksi dengan Trypanosoma evansi. Pada manusia penderita terinfeksi Trypanosomiasis, gejalanya adalah kejangkejang bahkan sampai mengakibatkan kematian (Shegokar et al, 2006; Mastra, 2011; Desquesnes et al, 2013).

Para ahli menduga terdapat gangguan sistem imun pada ternak penderita Trypanosomiasis. Sel $T$ helper (Th) sangat berperan pada sistem pertahanan tubuh terutama dalam menghadapi infeksi parasit. Salah satu sitokin yang diproduksi sel Th adalah tumor necrosis factor (TNF- $\alpha$ ) yang berperan penting dalam mengeliminasi parasit Trypanosoma evansi. TNF- $\alpha$ bertugas secara sinergis dalam fagositosis oleh makrofag yang terinfeksi parasit Trypanosoma evansi. Terjadinya gangguan atau penurunan aktivitas sel Th dan sitokinnya yaitu TNF- $\alpha$ dan akan sangat mempengaruhi mekanisme pertahanan tubuh terhadap penyakit Trypanosomiasis. Pemeriksaan kadar Tumor Necrosis Factor (TNF- $\alpha$ ) sangat penting dilakukan karena untuk memastikan bagaimana keberhasian mekanisme pertahanan tubuh hospes 
Pengaruh Infeksi Trypanosoma evansi terhadap Kadar TNF- $\alpha$ dan Perubahan Histopatologi... Ady Kurnianto, Junianto Wika Adi Pratama, Miranti Candrarisna

melawan agen infeksius parasit Trypanosoma evansi (Habila et al, 2012; (Bal et al, 2012).

Organ hepar merupakan organ dalam tubuh terbesar dan merupakan pusat metabolisme yang paling kompleks di dalam tubuh. Melihat peranan hepar yang komplek, maka apabila terjadi kerusakan ataupun kelainan pada hepar akan mempengaruhi fungsi jaringan tubuh yang lainnya (Tantawet et al, 2011). Hepar sebagai pusat metabolisme tubuh, masuknya antigen Trypanosoma evansi yang diinokulasi ke dalam tubuh tikus putih secara subcutan akan dimetabolisme di dalam hepar, sehingga akan menimbulkan gangguan dan kerusakan pada organ hepar akibat infeksi Trypanosoma evani (Ibrahim et al, 2010; Mekata et al, 2013).

Degenerasi sel sering diartikan sebagai kehilangan struktur normal sel sebelum kematian. Umumnya hal ini disebabkan oleh agen infeksi, bahan toksik, disfungsi nutrisi, dan umur tua. Hepar mempunyai peranan penting dalam pengaturan lemak tubuh, proses sintesis dan transport lipoprotein dilakukan di hati. Gangguan sintesis protein dan fosfolipid berpotensi menghambat sintesis dan sekresi lipoprotein. Nekrosis merupakan kematian sel atau jaringan pada organisme hidup. Secara mikroskopis terjadi perubahan intinya yaitu hilangnya gambaran kromatin, inti menjadi keriput, tidak vasikuler lagi, inti tampak lebih padat, warnanya gelap hitam (piknosis), inti terbagi atas fragmen-fragmen, robek (karioreksis), inti tidak lagi mengambil warna banyak karena itu pucat tidak nyata (kariolisis) (Tantawet et al, 2011; Bal et al, 2012).

Perubahan struktur histologis hepar ini dipengaruhi oleh jumlah dan jenis paparan infeksi yang masuk ke dalam organ hepar, termasuk perlakuan pemberian infeksi Trypanosoma evansi pada suatu individu. Pemakaian isolat pada penelitian ini mengunakan Trypanosoma evansi isolat Sumbawa. yang mempunyai sifat patogen dan memiliki profil yang konstan setelah diinokulasi atau pasase berulang pada hewan (Mastra, 2011). Pemilihan jalur pemberian infeksi secara subcutan sejauh ini jarang digunakan para peneliti lain dibandingkan dengan jalur intraperitoneal. Perbedaan antara jalur pemberian secara subcutan dan intraperitoneal terletak pada kecepatan periode prepaten. Jalur pemberian melalui subcutan periode prepatennya lebih lama daripada jalur intraperitoneal (Subekti et al, 2013).

Penelitian ini menganalisis kadar TNF- $\alpha$ sebagai sitokin proinflamasi pada sistem pertahanan tubuh serta menganalisis derajat kerusakan hepar pada 
tikus putih (Rattus norvegicus) yang diinfeksi Trypanosoma evansi isolat Sumbawa secara subcutan.

\section{BAHAN DAN METODE}

Penelitian bersifat eksperimental laboratorik dengan desain penelitian Rancangan Acak Lengkap (RAL). Protokol kerja yang dilakukan antara lain infeksi Trypanosoma evansi didasarkan pada analisis uji serologis Enzyme Linked Immunosorbent Assay atau ELISA. Skoring derajat kerusakan hepar menggunakan metode Knodell (2000). Analisis statistik hasil pemeriksaan nilai Optical Density (OD) kadar sitokin TNF- $\alpha$ antara kelompok kontrol dan kelompok perlakuan disajikan dalam bentuk rerata (Mean $\pm S D$ ), dilanjutkan dengan analisis parametrik anova. Analisis statistik data pada penelitian ini untuk mengetahui derajat kerusakan hepar tikus putih antara kelompok kontrol dan kelompok perlakuan dengan uji Kruskall Wallis dan dilanjutkan Mann Whitney test.

\section{Alat dan Bahan}

Plasma darah tikus putih terinfeksi Trypanosoma evansi isolat Sumbawa (P029) untuk uji ELISA, alkohol 70\%, methanol absolut, Giemza, EDTA, infus $\mathrm{NaCl}$ fisiologis 0,9\%. Parasit Trypanosoma evansi isolat Sumbawa diperoleh dari
Bagian Parasit di Balai Besar Penelitian Veteriner (BBalivet) Jl. R.E. Martadinata Bogor beserta sertifikat analisis. Alat alat yang digunakan: syringe $1 \mathrm{ml}$, tabung venoject, mikroskop cahaya merk Nikon H600L yang dilengkapi digital camera DS Fi2 300 megapixel, serbuk gergaji, kandang dan peralatan makan minum tikus dan pakannya. Hewan coba tikus putih dewasa jenis kelamin jantan (Rattus norvegicus) galur Wistar berat badan 200-250gram sebanyak 30 ekor yang diperoleh dari peternakan tikus EXO GRIMM Surabaya. Tikus putih yang diperoleh dalam kondisi sehat, lincah, dan nafsu makan baik dan dilengkapi sertifikat kesehatan. Sebelum digunakan dalam penelitian, tikus putih diadaptasikan selama 1 minggu dan dilakukan pengurusan surat animal ethical clearence (kelayakan hewan coba penelitian) di FKH Universitas Airlangga.

\section{Metode penelitian:}

Penelitian dilaksanakan pada bulan September 2015-Februari 2016 di Fakultas Kedokteran Hewan Univesitas Airlangga di Surabaya.

\section{Prosedur Penelitian}

\section{Pemeriksaan dengan mouse \\ inoculation test (MIC)}

Teknik ini selain untuk mendeteksi ada atau tidak adanya parasit, juga untuk 
Pengaruh Infeksi Trypanosoma evansi terhadap Kadar TNF- $\alpha$ dan Perubahan Histopatologi... Ady Kurnianto, Junianto Wika Adi Pratama, Miranti Candrarisna

mendapatkan Trypanosoma evansi yang hanya tumbuh di dalam tubuh tikus. Isolat yang dipakai dalam penelitian ini berasal dari mencit yang sebelumnya diinfeksi Trypanosoma evansi isolat Sumbawa. Trypanosoma evansi yang dinfeksi pada mencit (Mus musculus) dalam waktu 1-2 hari tersebut, akan berkembang biak dalam darah mencit. Ketika jumlah Trypanosoma evansi dalam darah mencapai lebih dari 20 per lapangan pandang mikroskop (200x) atau positif empat (++++) maka mencit tersebut dapat digunakan untuk menginokulasi ke tikus putih (Rattus norvegicus). Metode inokulasi atau pasase Trypanosoma evansi ke tikus putih (Rattus norvegicus) dilakukan dengan penyuntikan darah mencit secara subcutan. Pengambilan darah mencit sebanyak $0,3 \mathrm{ml}$ yang mengandung $T$. evansi $10^{6}$ disuntikkan pada tikus putih secara subcutan, kemudian tikus diamati selama 1 minggu dengan diperiksa darahnya setiap hari.

\section{Perlakuan pada hewan coba:}

Populasi sampel tikus putih (Rattus norvegicus) yang digunakan untuk penelitian dibagi 5 kelompok perlakuan yaitu:
Po : kelompok tikus putih berjumlah 6 ekor sebagai kontrol diinjeksi $\mathrm{NaCl}$ fisiologis secara subcutan dengan dosis $0,3 \mathrm{ml}$, pengambilan sampel darah dan organ hepar pada hari ke 7 pasca injeksi $\mathrm{NaCl}$ fisiologis.

$P_{1}$ : kelompok tikus putih berjumlah 6 ekor sebagai perlakuan infeksi Trypanosoma evansi isolat Sumbawa secara subcutan dengan dosis 0,3 $\mathrm{ml} / \mathrm{sc}$, pengambilan sampel darah dan organ hepar pada hari pertama pasca infeksi Trypanosoma evansi

$P_{2}$ : kelompok tikus putih berjumlah 6 ekor sebagai perlakuan infeksi Trypanosoma evansi isolat Sumbawa secara subcutan dengan dosis 0,3 $\mathrm{ml} / \mathrm{sc}$, pengambilan sampel darah dan organ hepar pada hari ke-3 pasca infeksi Trypanosoma evansi

$P_{3}$ : kelompok tikus putih berjumlah 6 ekor sebagai perlakuan infeksi Trypanosoma evansi isolat Sumbawa secara subcutan dengan dosis: 0,3 $\mathrm{ml} / \mathrm{sc}$, pengambilan sampel darah dan organ hepar pada hari ke-5 pasca infeksi Trypanosoma evansi

$P_{4}$ : kelompok tikus putih berjumlah 6 ekor sebagai perlakuan infeksi Trypanosoma evansi isolat Sumbawa secara subcutan dengan dosis 0,3 $\mathrm{ml} / \mathrm{sc}$, pengambilan sampel darah dan 
organ hepar pada hari ke-7 pasca infeksi Trypanosoma evansi

\section{Pembuatan preparat histologi hepar} dengan Pewarnaan hematoxylin eosin (HE)

Tahap pembuatan sediaan histologi dilakukan sesuai metode Kiernan (1990). Fiksasi jaringan hepar dengan cara merendam dalam formalin buffer fosfat $10 \%$ selama 24 jam, kemudian diiris (trimming) agar dapat dimasukkan dalam kotak untuk diproses dalam tissue processor. Jaringan hepar dimasukkan ke dalam alkohol 70\%, alkohol 80\%, alkohol $90 \%$, alkohol 96\%, toluene 1 dan toluene 2 masing-masing selama 2 jam. Selanjutnya jaringan dimasukkan ke dalam paraffin cair dengan suhu $56^{\circ} \mathrm{C}$ selama 2 jam sebanyak 2 kali. Jaringan hepar kemudian diambil dengan pinset, dilanjutkan dengan menggunakan parafin blok. Pemotongan (cutting) dilakukan dengan menggunakan mikrotom dengan ketebalan 4-5 $\mathrm{mm}$. Jaringan yang terpotong dikembangkan di atas air dalam waterbath, kemudian ditempatkan pada gelas objek. Selanjutnya dikeringkan dalam suhu kamar dan preparat siap diwarnai dengan hematoxylin $\operatorname{eosin}(\mathrm{HE})$.

Tahapan pewarnaan HE dilakukan mengikuti metode Harris (1900), sebagai berikut preparat di atas gelas objek direndam dalam xylol I selama 5 menit, dilanjutkan xylol II, III masing-masing 5 menit. Kemudian preparat direndam dalam alkohol $100 \%$ I dan II masing-masing 5 menit, selanjutnya ke dalam aquades dan kemudian direndam dalam Harris hematoxylin selama 15 menit. Dicelupkan ke dalam aquades dengan cara mengangkat dan menurunkan. Preparat kemudian dicelupkan ke dalam acid alkohol $1 \%$ selama 7-10 celupan, direndam dalam aquades 15 menit, dan dalam eosin selama 2 menit. Selanjutnya preparat direndam dalam alkohol 96\% I dan II masing-masing 3 menit, alkohol 100 \% I dan II masingmasing 3 menit, dan dalam xylol IV dan V masing-masing 5 menit. Preparat dikeringkan dan dilakukan mounting dengan menggunakan entelan. Preparat diperiksa di bawah mikroskop untuk pemeriksaan terhadap perubahan histologi hepar.

\section{Pemeriksaan sitokin TNF- $\alpha$ dengan ELISA}

Sampel darah tikus putih diambil masingmasing sebanyak $1 \mathrm{ml}$ dan dimasukkan dalam tabung berisi EDTA, kemudian digoyang berulang. Tabung sampel darah disentrifugasi dengan kecepatan 1500 rpm selama 15 menit. Darah yang telah disentrifugasi akan terpisah menjadi eritrosit, lapisan buffy coat dan plasma darah. Plasma dipisahkan dan disimpan 
Pengaruh Infeksi Trypanosoma evansi terhadap Kadar TNF- $\alpha$ dan Perubahan Histopatologi... Ady Kurnianto, Junianto Wika Adi Pratama, Miranti Candrarisna

dalam microtube. Kemudian microtube yang berisi plasma disimpan dalam freezer dengan suhu $-20^{\circ} \mathrm{C}$ sampai akan digunakan. Plasma darah dikeluarkan dan diletakkan pada suhu kamar, kemudian dilakukan coating antigen $(\mathrm{Ag})$. Proses coating antigen dilakukan pengenceran $\mathrm{Ag}$ (plasma) dengan buffer carbonat (coating buffer) dengan perbandingan $1: 3$ yaitu $\mathrm{Ag}$ (plasma) sebanyak $125 \mu \mathrm{l}$ dan buffer carbonat (coating buffer) sebanyak $375 \mu \mathrm{l}$ kemudian masuk ke dalam tabung eppendorf. Setelah itu diambil dan dimasukkan sebanyak $100 \mu \mathrm{l} /$ well ke dalam mikroplate (well) dari eppendof yang berisi $\mathrm{Ag}$ (plasma) dan buffer carbonat (coating buffer). Kemudian mikroplate (well) ditutup dengan plastik, inkubasi selama 18 jam pada suhu $4^{\circ} \mathrm{C}$. Selanjutnya dilakukan pencucian dengan mengunakan washing buffer $200 \mu \mathrm{l} /$ well sebanyak tiga kali, kemudian dilakukan proses blocking. Blocking terdiri dari creamer 4\% (PBS $25 \mathrm{ml}$ + creamer $1 \mathrm{~g}+$ tween 0,125 ml) dalam PBST 0,5\%, tutup plastik kemudian inkubasi selama 2 jam dengan suhu $37^{\circ} \mathrm{C}$. Setelah itu dicuci dengan mengunakan washing buffer $200 \mu \mathrm{l} /$ well sebanyak tiga kali. Antibodi (Ab) primer (TNF- $\alpha$ ) sebanyak 100 $\mu \mathrm{l} /$ well dituangkan. Antibodi (Ab) primer terdiri dari TNF- $\alpha$ dengan pengenceran masing-masing $1: 1000$ dalam PBS (TNF- $\alpha$ $=5 \mu \mathrm{l}:$ PBS $=5 \mathrm{ml}:$ PBS $=5 \mathrm{ml}$ ). Setelah itu microplate (well) ditutup plastik dan inkubasi selama 1 jam dengan suhu $37^{\circ} \mathrm{C}$. Selanjutnya dilakukan pencucian dengan washing buffer $200 \mu \mathrm{l} /$ well sebanyak tiga kali. Setelah itu tuangkan antibodi (Ab) sekunder (Rabbit anti sheep IgG) sebanyak $100 \mu \mathrm{l} /$ well. Antibodi (Ab) sekunder terdiri dari Rabbit anti sheep IgG dengan pengenceran $1: 2000$ dalam PBS (Rabbit = $5 \mu \mathrm{l}:$ PBS $=10 \mathrm{ml}$ ). Kemudian cuci microplate dengan washing buffer 200 $\mu \mathrm{l} /$ well tiga kali. Selanjutnya dibuat sediaan p-Nitrophenyl Phosphatase atau p-NPP (1 $\mathrm{mg} / \mathrm{ml}$ ) dalam $10 \mathrm{ml}$ buffer subtrat pada tabung eppendof, selanjutnya dimasukkan ke dalam mikroplate (well) sebanyak 100 $\mu \mathrm{l} /$ well dari eppendof. Inkubasi diruang gelap dengan suhu kamar $\left(37^{\circ} \mathrm{C}\right)$ selama 15 menit selanjutnya diamati perubahan warna. Reaksi dihentikan dengan $\mathrm{NaOH} 4 \mathrm{~N}$ $50 \mu \mathrm{l}$. Pembacaan dengan ELISA reader dengan frekuensi gelombang $405 \mathrm{~nm}$.

\section{HASIL DAN PEMBAHASAN}

\section{Hasil Pemeriksaan Sitokin TNF-dengan ELISA}

Hasil penelitian dari 30 sampel plasma darah yang diteliti berhasil menunjukkan perbedaan rerata nilai Optical Density (OD) sitokin TNF- $\alpha$ terhadap derajat parasitemia pada tikus putih yang terinfeksi Trypanosma evansi isolat Sumbawa dengan ELISA 
ISSN 1978-2071 (Print); ISSN 2580-5967 (Online) Jurnal IImiah Kedokteran Wijaya Kusuma 8(1) : 26-39, Maret 2019

Tabel 1. Rerata nilai Optical Density (OD) TNF- $\alpha$ pada kelompok kontrol dan kelompok perlakuan

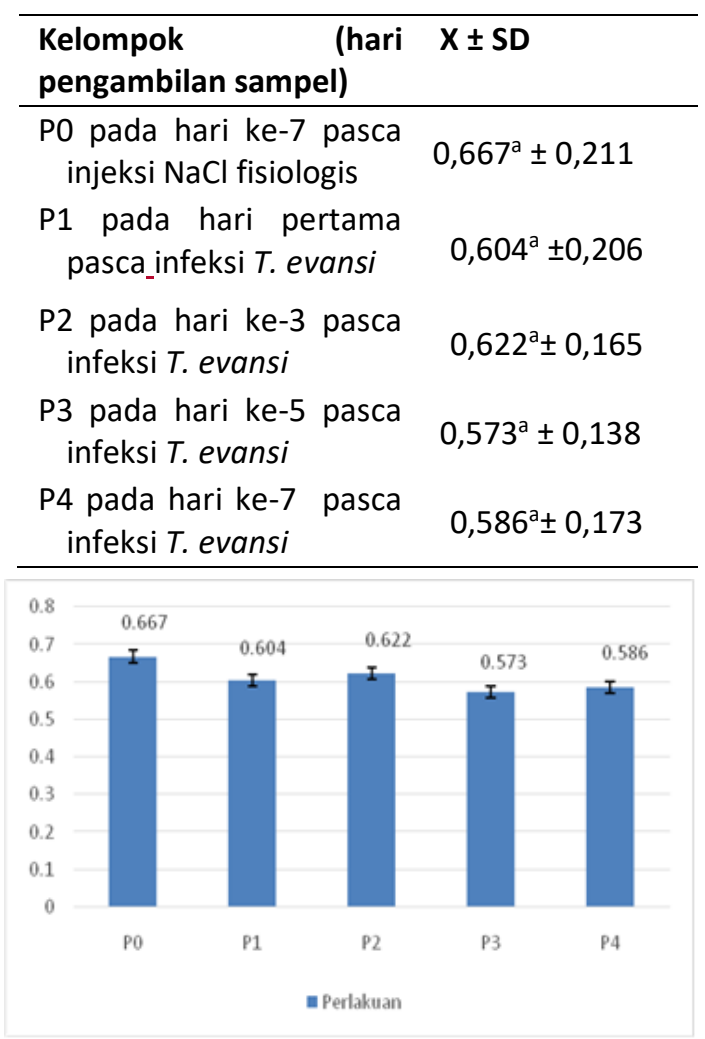

Gambar 1. Diagram batas nilai Optical Density (OD) TNF- $\alpha$ pada kelompok kontrol dan kelompok perlakuan
Metode penilaian hasil skoring kerusakan hepar tikus putih yang diinfeksi T. evansi dilakukan penjumlahan skor degenerasi, nekrosis dan portal inflamasi pada 5 lapang pandang yang terdapat dalam satu preparat histopatologi hepar masing-masing kelompok perlakuan. Penilaian skoring kerusakan hepar sesuai Knodell et al, 2007, yaitu;

\section{Nilai scoring:}

$1=$ ditemukan $25 \%$ degenerasi, nekrosis atau portal inflamasi dalam satu lapang pandang

$2=$ ditemukan $50 \%$ degenerasi, nekrosis atau portal inflamasi dalam satu lapang pandang

$3=$ ditemukan $75 \%$ degenerasi, nekrosis atau portal inflamasi dalam satu lapang pandang

$4=$ ditemukan $>75 \%$ degenerasi, nekrosis atau portal inflamasi dalam satu lapang pandang

Tabel 2. Hasil skoring kerusakan hepar pada tikus putih yang diinfeksi T. evansi

\begin{tabular}{|c|c|c|c|}
\hline Bentuk & Skor & Keterangan & Kelompok \\
\hline Degenerasi & 1 & Perubahan degeneratif $<25 \%$ & P01, P42 \\
\hline Degenerasi & 3 & Perubahan degeneratif $51-75 \%$ & P33 \\
\hline Degenerasi & 4 & Perubahan degeneratif $>75 \%$ & P31, P32, P34 \\
\hline Nekrosis & 4 & Nekrosis terjadi $<25 \%$ & P01, P02, P04, Seluruh P1, P22, P23, P42 \\
\hline Nekrosis & 6 & Nekrosis terjadi antara $26-50 \%$ & P21, P31, P33 P34 \\
\hline Nekrosis & 8 & Nekrosis terjadi $>50 \%$ & P24 \\
\hline Nekrosis & 10 & Nekrosis pada $25-50 \%$ disertai bridging necrosis & P32 \\
\hline Nekrosis & 12 & Nekrosis terjadi $>50 \%$ disertai bridging necrosis & $\mathrm{P} 43, \mathrm{P} 44$ \\
\hline Nekrosis & 14 & Diffuse necrosis $>76 \%$ merata pada semua lobulus & P41 \\
\hline P.inflamasi & 1 & $\begin{array}{l}\text { Ditemukan sel radang }<1 / 3 \text { total area segitiga } \\
\text { Kiernan's }\end{array}$ & P01, P03, P04 P13, P21, P24 P34 \\
\hline P.inflamasi & 3 & $\begin{array}{l}\text { Ditemukan sel radang } 1 / 3-2 / 3 \text { total area segitiga } \\
\text { Kiernan's }\end{array}$ & P14, P22, P23 \\
\hline P.inflamasi & 5 & $\begin{array}{l}\text { Ditemukan sel radang }>2 / 3 \text { total area segitiga } \\
\text { Kiernan's }\end{array}$ & P31, P32, P33 dan seluruh P4 \\
\hline
\end{tabular}



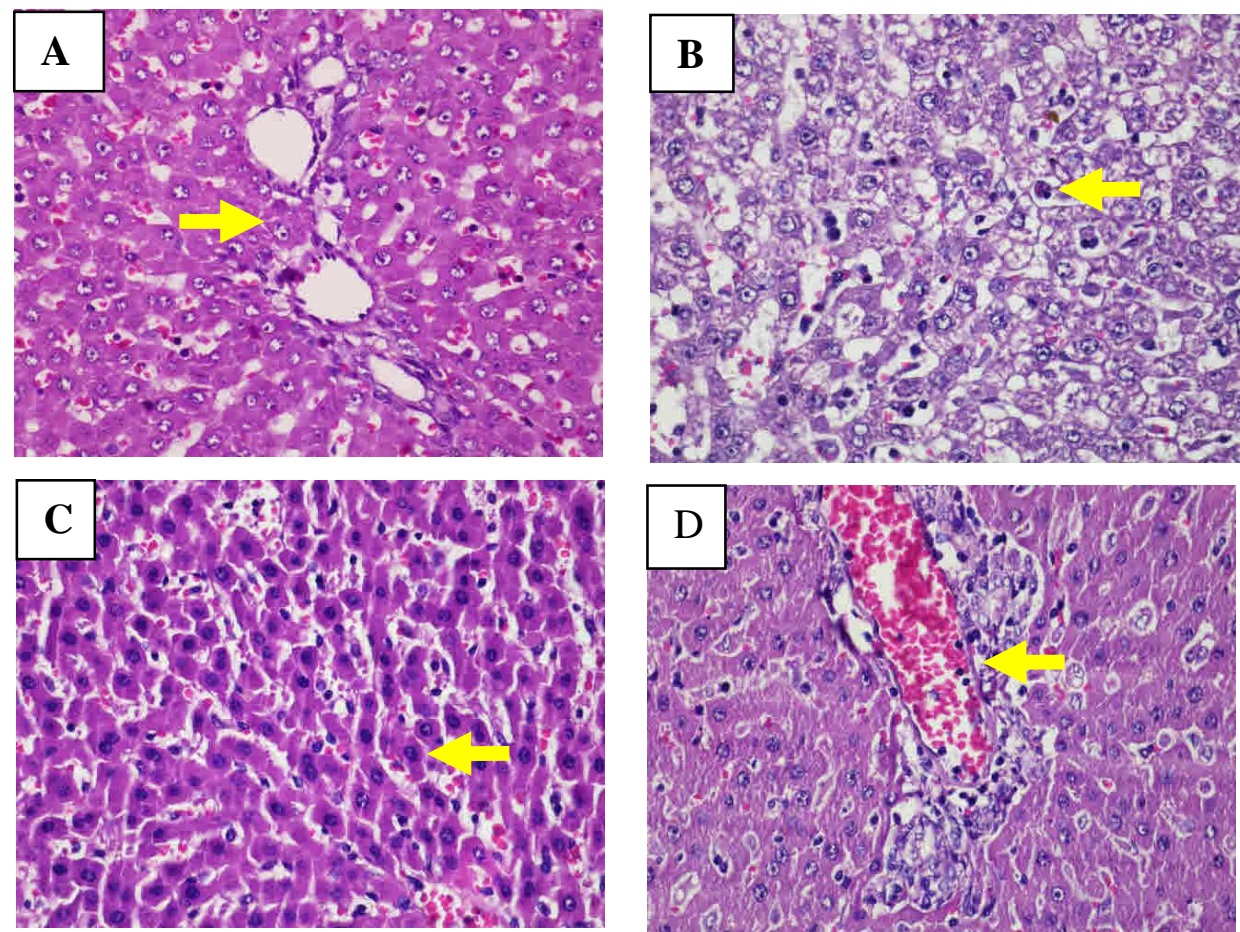

Gambar 2. Struktur histopatologi hepar tikus putih yang di infeksi Trypanosoma evansi

\section{Keterangan gambar:}

A. Struktur histopatologi hepar tikus putih normal; area portalis pada kelompok kontrol nampak normal (panah)

B. Struktur histopatologi hepar tikus putih mengalami degenerasi; area vena centralis terlihat sitoplasma kosong atau seperti ruang kosong, perubahan ini disebut degenerasi hidropik (panah)

C. Struktur histopatologi hepar tikus putih mengalami nekrosis; nekrosis (nekrosis centrolobular) pada sel-sel hepatosit, dan bridging necrosis (kematian sel yang menyambung antara $v$. centralis ke $v$. centralis atau $v$. centralis ke segitiga kiernan) (panah)

D. Struktur histopatologi hepar tikus putih mengalami portal inflamasi; adanya sel radang dan peningkatan aktivitas proliferasi dari sel-sel epitel ductus interlobularis (panah).

(Pemeriksaan dengan mikroskop Nikon H600L; camera DS Fi2 300 megapixel, pembesaran 400x)

\section{PEMBAHASAN}

Berdasarkan hasil pemeriksaan rerata nilai Optical Density (OD) atau kadar sitokin TNF- $\alpha$ kelompok perlakuan P3= $0,573^{\mathrm{a}} \pm 0,138$ dan $P 4=0,586^{\mathrm{a}} \pm 0,173$ menunjukkan tidak terdapat perbedaan secara signifikan antara tikus putih kelompok kontrol $\mathrm{PO}=0,667^{\mathrm{a}} \pm 0,211$ $(p=0,624, p>0,05)$. Pada penelitian ini diperoleh hasil terjadi sedikit penurunan kadar TNF- $\alpha$. Penurunan kadar TNF- $\alpha$ dalam tubuh menyebabkan sel endotel vaskuler mengekspresikan reseptor permukaan yang baru (molekul adesi) pada permukaan pembuluh darah, sehingga permukaan sel endotel menjadi adesif untuk leukosit dan menginduksi terjadinya inflamasi akut (Abbas et al, 2015). Peningkatan kadar TNF- $\alpha$ pada serum tikus yang diinfeksi Trypanosoma menyebabkan terjadinya penghambatan replikasi Trypanosoma dalam makrofag secara in 
vitro. Ketika tikus yang diinfeksi Trypanosoma diberikan TNF- $\alpha$, hewan lebih cepat mati dibandingkan dengan kelompok kontrol tidak diberikan TNF- $\alpha$. Peranan TNF- $\alpha$ pada kasus Trypanosomiasis dapat menguntungkan dan merugikan tergantung pada level TNF$\alpha$ yang diproduksi selama infeksi. Pada kelinci yang diinfeksi Trypanosoma menyebabkan terjadinya syndrome cachexia berat yang ditandai dengan hipertrigliseridemia yang diperantarai TNF$\alpha$, hal ini terjadi karena TNF- $\alpha$ dapat menghambat kerja enzim lipoprotein lipase, bahkan dapat menimbulkan kematian (Ibrahim et al, 2010; Habila et al, 2012; Elhaig et al, 2013).

Hasil analisis data terhadap tingkat kerusakan pada hepar antara kelompok kontrol dan kelompok perlakuan menggunakan uji Mann Whitney test menunjukkan terjadinya perbedaan pada kerusakan hepar ditemukan lesi degenerasi $(p=0,0640)$, nekrosis $(p=0,029)$ dan portal inflamasi $(p=0,060)$ antara kelompok kontrol dan perlakuan. Perbedaan tingkat kerusakan hepar tergantung lamanya waktu infeksi Trypanosoma evansi pada tikus putih. Kerusakan hepar akibat infeksi Trypanosoma evansi dapat dipengaruhi beberapa faktor antara lain lama pemaparan penyakit seperti akut, subkronis atau kronis dan infeksi sekunder (Tantawet et al, 2011).

Kerusakan hepar berupa lesi degenerasi ditandai dengan adanya ruang kosong didalam sitoplasma sel di dekat atau sekitar nukleus (Mekata et al, 2010). Sementara itu pernyataan berbeda dari peneliti lain menyatakan hewan terinfeksi Trypanosoma evansi pada daerah sinusoid organ hepar tidak ditemukan adanya pelebaran serta tidak terdapat bentukan ruang kosong atau vacuola (Ibrahim et al, 2010). Perubahan lain yang dijumpai pada hepar adalah ditemukan adanya infiltrasi pada sel radang di vena centralis ataupun di segitiga Kiernan atau daerah perbatasan tiga lobuli atau lebih seperti cabang arteri hepatika, vena portae, duktus biliverus dan saluran limfe (Rjeibi et al, 2015).

Selanjutnya untuk mengetahui perbedaan kerusakan hepar digunakan uji Mann Whitney diperoleh hasil terdapat perbedaan bermakna $(p=0,029, p<0,05)$ terhadap lesi nekrosis antara kelompok kontrol dan perlakuan. Pada hepar yang mengalami nekrosis terdapat perubahan morfologi pada inti sel sebagai piknosis dan karyolisis. Hal ini ditandai hilangnya gambaran kromatin didalam intisel yang terjadi secara alami atau dikarenakan adanya kerusakan pada jaringan tubuh. Penelitian yang lain juga menyatakan bahwa nekrosis merupakan kematian sel 
Pengaruh Infeksi Trypanosoma evansi terhadap Kadar TNF- $\alpha$ dan Perubahan Histopatologi... Ady Kurnianto, Junianto Wika Adi Pratama, Miranti Candrarisna

secara mikroskopik. Pada nekrosis terjadi perubahan inti ditandai menghilangnya kromatin, inti menjadi keriput, inti tampak lebih padat, berwarna gelap (piknosis), dan inti terlihat pucat atau kariolisis (Tantawet et al, 2011; Bal et al, 2012).

\section{KESIMPULAN}

Kesimpulan penelitian adalah:

1. Penurunan kadar TNF- $\alpha$ antar kelompok tidak berbeda nyata secara signifikan nilai $(p=0,0624, p>0,05)$ dan tidak terdapat hubungan bermakna pada kadar TNF- $\alpha(p>0,05)$ (nilai $r=$ $0,056)$ antar kelompok pada tikus putih yang diinfeksi Trypanosoma evansi isolat Sumbawa.

2. Pemberian infeksi secara subcutan dapat menyebabkan kerusakan hepar berupa lesi degenerasi, nekrosis, dan portal inflamasi pada tikus putih yang diinfeksi Trypanosoma evansi isolat Sumbawa.

3. Kadar TNF- $\alpha$ menurun, mengakibatkan kerusakan hepar dan tingkat keganasan parasit Trypanosoma evansi isolat Sumbawa meningkat

\section{SARAN}

Perlu penelitian lanjutan untuk pemeriksaan ekspresi sitokin TNF- $\alpha$ atau sitokin yang lain seperti IFN- $\gamma$ dengan menggunakan metode imunohistokimia
(IHK) pada kasus Trypanosomiasis.

\section{DAFTAR PUSTAKA}

Abbas AK, Lichtman AH, Pober JS, 2015.

Cellular and Molecular Immunology. 8th ed. Philadelphia, WB Saunders Company.

Bal MS, Singla LD, Kumar H, Vasudev A, GuptaK, Juyal PD, 2012. Pathological studies onexperimental Trypanosoma evansi infectionin Swiss albino mice. J Parasit Dis. 36(2):260264.

Dargantes AP, Mercado RT, Dobson RJ, ReidS A, 2009. Estimating the impact ofTrypanosoma evansi infection (surra) onbuffalo population dynamics in southernPhilippines using data from cross-sectionalsurveys. Inter J for Parasitol. 39: 11091114.

Desquesnes $\mathrm{M}$, Holzmuller $\mathrm{P}$, Lai $\mathrm{DH}$, Dargantes A, Lun Zhao-Rong, and Jittaplapong S, 2013. Review Article. Trypanosoma evansi and Surra: A Review andPerspectives on Origin, History, Distribution, Taxonomy, Morphology, Hosts, and Pathogenic Effects. BioMed 
Research International. 2013.

Dobson RJ, Dargantes AP, Mercado RT, ReidSA, Dobson RJ, 2009. Models for Trypanosoma evansi (surra), its control andeconomic impact on small-hold livestockowners in the Philippines. Inter J forParasitol 39: 1115-1123.

Elhaig MM, Youssef Al, El-Gayar AK, 2013. Molecular and parasitological detection of Trypanosoma evansi in Camels in Ismailia, Egypt Vet Parasitol. 198: 214-218.

Habila N, Inuwa MH, Aimola IA, Udeh MU, Haruna E, 2012. Pathogenic mechanisms of Trypanosoma evansi infections. Researchin Vet Sci. 93: 13-17.

Ibrahim MA, Aliyu AB, Sallau AB, Bashir M, Yunusa I, and Umar TS, 2010. Sennaoccidentalis leaf extract possesses antitrypanosomal activity and ameliorates the trypanosome induced anemia and organ damage. Pharmacognosy Res. 2(3): 175-180.

Knodell RG, Ishak KG, Black WC, Chen TS, Craig R, Kaplowitz N, Kiernan, 2007. Formulation and application of a numerical scoring system for assessing histological activity in asymptomatic chronic active hepatitis. Hepatology 2007(1):431-435

Mastra IK, 2011. Seroprevalensi Trypanosomiasis Di Pulau Sumbawa, Propinsi Nusa Tenggara Barat. Buletin Veteriner, Bbvet Denpasar, 23(79).

Mekata H, Konnai S, Mingala CN, Abes NS, Gutierrez CA, et al, 2013. Isolation, cloning, and pathologic analysis of Trypanosoma evansi field isolates. Parasitol Res. 112(4):1513-1521.

Ngure RM, Ongeri B, Karori SM, Wachira W, Maathai RG, Kibugu JK, Wachira FN, 2009. Anti trypanosomal effect of Azattadiracta indica (neem) extract on Trypanosoma brucei rhodesiense infected mice. Eastern Journal of Medicine. 14:2-9.

Rjeibi MR, Hamida TB, Dalgatova Z, Mahjoub T, Rejeb A, Dridi W, Gharbi M, 2015. First report of surra (Trypanosoma evansi infection) in a Tunisian dog. 
Pengaruh Infeksi Trypanosoma evansi terhadap Kadar TNF- $\alpha$ dan Perubahan Histopatologi... Ady Kurnianto, Junianto Wika Adi Pratama, Miranti Candrarisna

Parasite 22(3): 1-4.

Shegokar VR, Powar RM, Joshi PP, Bhargava A, Dani VS, Katti R, Zare VR, Khanande ID, Jannin J, and Truc $P$, 2006. Human Trypanosomiasis caused by Trypanosomaevansi in a vllage in India: Prelimary serologic survey of the local population. AmJ Trop Med Hyg. 75(5): 869870.

Subekti DT, Sawitri DH, Wardhana AH, Suhardono, 2013. Pola Parasitemia dan Kematian Mencit yang Diinfeksi Trypanosoma evansi Isolat Indonesia. Bbalivet Bogor. JITV 18(4): 274-290.

Tantawet S, Willemse

B,
Taweethavornsawat $\mathrm{P}$, Kaeoket

K, 2011. Trypanosoma evansi infection in mice and sow: cryopreservation of $T$. evansi, its infectivity and subsequent clinical signs and pathological findings. Journal of Applied Animal Sci. 4(3): 31-37.

World Health Organization, 2010. Indicators of monitoring and evaluation of the Kalazar elimination programme, Tropical Disease Research, Agustus 2010.

World Health Organization, 2012. Parasit and neglected disease: The PAHO regional Program. Geneva: World Health Organization. 